\title{
The Pyridone-Annelated Isoindigo (5'-Cl) Induces Apoptosis, Dysregulation of Mitochondria and Formation of ROS in Leukemic HL-60 Cells
}

\author{
Ayman M. Saleh ${ }^{a, b}$ Ahmad Aljada ${ }^{a, b}$ Mustafa M. El-Abadelah ${ }^{c}$ Salim S. Sabric \\ Jalal A. Zahrac Amre Nasra, Mohammad A. Aziz ${ }^{\mathrm{b}}$
}

${ }^{a}$ Department of Basic Medical Sciences, College of Medicine, King Saud Bin Abdulaziz University for Health Sciences (KSAU-HS), National Guard Health Affairs, Riyadh, Kingdom of Saudi Arabia, 'King Abdullah International Medical Research Center (KAIMRC), National Guard Health Affairs, Riyadh, Kingdom of Saudi Arabia, 'Department of Chemistry, Faculty of Science, The University of Jordan, Amman, Jordan

\section{Key Words}

Pyridone-annelated isoindigo $\bullet$ Anticancer compound $\cdot$ Apoptosis $\bullet$ Mitochondria dysfunction - Reactive oxygen species (ROS) • Bcl-2 2 Bax $・$ Phosphorylation of Bcl-2 $\bullet$ HL-60 cells

\begin{abstract}
Background/Aims: In our quest to develop an isoindigo with improved efficacy and bioavailability, we recently synthesized a series of novel substituted pyridone-annelated isoindigo and evaluated their antiproliferative effects. We identified the compound $[(E)-1-$ (5'-Chloro-2'-oxoindolin-3'-ylidene)-6-ethyl-2,3,6,9-tetrahydro-2,9-dioxo-1H-pyrrolo[3,2-f] quinoline-8-carboxylic acid], abbreviated as $5^{\prime}-\mathrm{Cl}$, which shows selective antiproliferative activities against various cancer cell lines mediated through apoptosis. Here we have investigated the molecular mechanisms underlying the apoptotic activity of $5^{\prime}-\mathrm{Cl}$ in the human promyelocytic leukemia HL-60 cells. Methods: We employed different methods to determine the apoptotic pathways triggered by $5^{\prime}-\mathrm{Cl}$ in $\mathrm{HL}-60$ cells, using flow cytometry, nuclear staining, caspases activation, mitochondria functioning, generation of reactive oxygen species (ROS) and Western blotting techniques. Results: Low concentrations (1-8 $\mu \mathrm{M})$ of 5'$\mathrm{Cl}$ inhibited the growth of $\mathrm{HL}-60$ cells in a dose and time-dependent manner. Cytotoxicity of this compound is found to be mediated by a caspase-dependent apoptosis. Also, there were indications of caspase independent apoptosis as z-VAD-FMK failed to fully rescue the cells from 5 '-Cl-induced apoptosis. In addition, the compound triggered generation of Reactive Oxygen Species (ROS), caused depolarization of the mitochondrial inner membrane, decreased the level of cellular ATP, modulated the expression and phosphorylation of $\mathrm{Bcl}-2$ leading to loss of its association with Bax and increased the release of cytochrome $c$ to the cytosol of treated




\section{Cellular Physiology Cell Physiol Biochem 2015;35:1958-1974

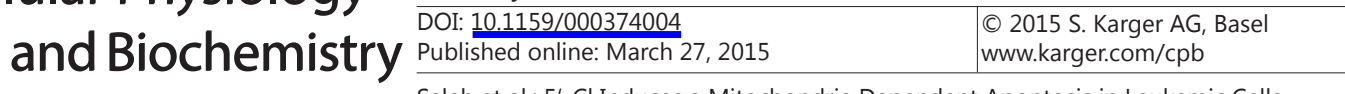

cells. The effects of $5^{\prime}-\mathrm{Cl}$ on mitochondria and apoptosis were substantially blocked in the presence of a combination between Z-VAD-FMK and either of the ROS scavenger N-acetyl-Lcysteine (NAC) or pyrrolidine dithiocarbamate (PDTC). Conclusion: We demonstrated that the growth inhibitory effects of $5^{\prime}-\mathrm{Cl}$ in $\mathrm{HL}-60$ cells involve multiple pathways of apoptosis and dysregulation of mitochondrial functions

Copyright (C 2015 S. Karger AG, Basel

\section{Introduction}

Acute myeloid leukemia (AML) is hematopoietic malignancy characterized by uncontrolled proliferation and accumulation of myeloblasts in the bone marrow, blood, and other organs $[1,2]$. AML is the most common type of acute leukemia in adults and its prognosis vary, depending on age and the stage of the disease [3]. Patients typically respond to initial treatment with anthracycline and cytarabine-based chemotherapy [3]. However, the response to chemotherapy is poor or short-lived, and the therapeutic options are limited in elderly relapsed patients. The inadequacy of conventional therapy for AML has fueled extensive efforts to seek novel and more potent drugs to improve treatment outcomes.

The bis-indole-containing alkaloids indigo, indirubin and isoindigo, have been employed in treating myeloid leukemia. Indirubins and meisoindigo (1-methyl isoindigo) were used for treatment of chronic myelogenous leukemia (CML) [4]. However the clinical application of these drugs in treating leukemia is opposed by their potential severe side effects, poor water solubility, bone marrow suppression and drug-resistance in prolonged treatments [4]. Similarly, the isoindigo Natura ${ }^{\mathrm{m}}, 1$, 1-( $\beta$-D-triacetylxylopyranosyl) isoindigo, was synthesized which showed antiproliferative activities that are only slightly better than those of meisoindigo in different cancer cell lines [5]. Like meisoindigo, Natura"' induced apoptosis, inhibited CDKs (cyclin-dependent kinases) and arrested tumor growth in mice [5]. However, Natura ${ }^{m}$ is almost completely insoluble in water which hinders its applications in chemotherapy.

Extensive efforts have recently been directed to synthesize novel indirubins and isoindigos with increased bioavailability and bioactivity. Several of these compounds have been shown to inhibit CDKs and glycogen-synthase kinase (GSK-3 $\beta$ ) with varying degrees of potency [4-13]. Recently, a novel 7-azaisoindigo derivative [namely N(1)-( $n$-butyl)-7azaisoindigo] has been shown to trigger apoptosis through reactive oxygen species (ROS) and deregulation of the mitochondrial functions [14]. In spite of the extensive studies aimed towards understanding the mode of action of these isoindigos in malignancies, there are gaps in our understanding of their cellular targets. In addition, the limited water solubility of these compounds hinders the detailed characterization of their antiproliferative signaling pathways.

Successful chemotherapeutics are able to trigger selective death of cancer cells through apoptosis [15]. Anticancer drugs can induce the extrinsic (receptor-mediated) pathway which involves ligation of death receptors, resulting in recruitment and activation of caspase-8 [15]. Alternatively, these drugs may stimulate the intrinsic (mitochondria-dependent) pathway of apoptosis which is evoked by the release of mitochondrial apoptogenic factors such as cytochrome $\mathrm{c}$ to the cytosol allowing activation of caspase-9 [16,17]. Following activation of the initiator caspase- 8 or caspase- 9 , the two pathways converge on the activation of terminal caspases (caspase- $3,-6$ and -7 ), which finally execute the death process by cleaving various substrates required for cell survival and maintaining the integrity of the genomic DNA [15].

In line with studies aiming to synthesize more soluble and effective anticancer isoindigo derivatives, we recently reported the synthesis of a novel series of pyridone-annelated isoindigo and evaluated their cytotoxic activities against various cancer cell lines [18]. Our analyses have identified the compound [(E)-1-(5'-Chloro-2'-oxoindolin-3'-ylidene)-6-ethyl2,3,6,9-tetrahydro-2,9-dioxo-1H-pyrrolo[3,2-f]quinoline-8-carboxylic acid] (known here as 5 '-Cl, Figure 1A) which strongly inhibits the growth of human hematological and solid tumor cell lines at low concentrations, but not noncancerous cells, suggesting its high efficacy and 


\section{Cellular Physiology Cell Physiol Biochem 2015;35:1958-1974 \begin{tabular}{c|l}
\hline DOI: 10.1159/000374004 & (C) 2015 S. Karger AG, Basel
\end{tabular} and Biochemistry Published online: March 27, $2015 \quad$ www.karger.com/cpb}

selectivity as antitumor agent [18]. Our more recent work shows that 5 '-Cl can also inhibit the proliferation of HL-60 (human acute myelogenous leukemia) cells through arresting the cell cycle at G0/G1, by modulating the expression and functions of the G1 phase-related proteins and inhibiting the kinase activities of CDK2 and CDK4 [19].

In this report, we demonstrate that 5 '- $\mathrm{Cl}$ induces a caspase-dependent and caspaseindependent apoptosis in HL-60 cells. In addition, 5 '-Cltriggers depolarization of mitochondria in these cells and elicit production of ROS. Furthermore, the compound suppresses the expression of antiapoptotic protein Bcl-2 and promotes its hyperphosphorylation leading to loss of functional association with the proapoptotic factor Bax, and subsequent release of cytochrome c from mitochondria to the cytoplasm.

\section{Materials and Methods}

\section{Reagents}

The pyridone-annelated isoindigo 5'-Cl compound [[(E)-1-(5'-Chloro-2'-oxoindolin-3'-ylidene)6-ethyl-2,3,6,9-tetrahydro-2,9-dioxo-1H-pyrrolo[3,2-f]quinoline-8-carboxylic acid] was previously synthesized and fully characterized in our recent publication [18]. Cytarabine, DMSO (dimethyl sulfoxide), components of lysis, mitochondria isolation and immunoprecipitation buffers, protease inhibitors (PMSF, pepstatin A, leupeptin, and aprotinin), Hoechst 33342 fluorescent stain, and the antioxidants NAC ( $N$-AcetylL-cysteine) and PDTC (Pyrrolidine Dithiocarbamate) were procured from Sigma Aldrich (St Louis, Missouri, USA). HL-60 cell line was obtained from American Type Culture Collection (ATCC; Manassas, Virginia, USA). Cell culture medium (RPMI 1640), penicillin-streptomycin, trypsin, PBS, and heat inactivated fetal bovine serum (FBS) were purchased from Invitrogen (Invitrogen, Carlsbad, California, USA). Cell culture grade disposable materials are from Corning Life Sciences (Tewksbury, Massachusetts, USA). The colorimetric tetrapeptide substrates for caspase-2 (Ac-VDVAD-pNA), caspase-8 (Ac-IETD-pNA), caspase-9 (Ac-LEHDpNA), caspase-3/-7 (Ac-DEVD-pNA) and caspase-6 (Ac-VEID-pNA), and the general caspase inhibitor (z-VADFMK) were purchased from BioVision, Inc. (Milpitas, California, USA). The antibodies against caspases and Phospho-Bcl-2 were from Cell Signaling Technology (Beverly, Massachusetts, USA), while the ones for cytochrome c, $\alpha$-tubulin, $\beta$-actin and Bcl-2 family proteins were obtained from Santa Cruz Biotechnology (Santa Cruz, California, USA).

\section{Cell culture conditions}

The human acute promyelocytic leukemia HL-60 cell line (ATCC ${ }^{\circledR}$ CCL-240 ${ }^{\mathrm{m}}$ ) was maintained in RPMI1640 medium supplemented with $10 \%(\mathrm{v} / \mathrm{v})$ heat inactivated FBS, penicillin G (100U/mL) and streptomycin $(100 \mathrm{mg} / \mathrm{mL})$, and kept at $37^{\circ} \mathrm{C}$ in a $5 \% \mathrm{CO}_{2} / 95 \%$ humidified incubator. Cells were seeded at an appropriate density according to each experimental design.

\section{Cell viability assay}

The quantitative determination of viable cells after various treatments was performed by using the dual DNA intercalating fluorescent dyes kit from EMD Millipore Bioscience (Muse ${ }^{\mathrm{TM}}$ Cell Count \& Viability Assay). Briefly, $3 \times 10^{5}$ HL-60 cells/mL in RPMI-1640 medium were seeded in each well of a 24 well-plate. After $24 \mathrm{~h}$, increasing concentrations of 5 '- $\mathrm{Cl}(0.0$ to $16.0 \mu \mathrm{M})$ were added using stock solutions of 1000 -fold the final concentration of the compound in 50\% DMSO: 50\% PBS, and incubated for $24 \mathrm{~h}$ in a 5\% CO2-cell culture incubator. Alternatively, cultured cells were treated with $4.0 \mu \mathrm{M} 5$ '-Cl for different time-points $(0$ to $72 \mathrm{~h}$ ) before analysis. At the end of exposure period, samples were incubated with the Cell Count \& Viability reagent for $5 \mathrm{~min}$, the viability of HL-60 treated cells were analyzed using the flow cytometry based Muse $\mathrm{e}^{\mathrm{TM}}$ Cell Analyzer (EMD Millipore Bioscience, Darmstadt, Germany) according to the manufacture's protocol. The viability of treated HL-60 cells was calculated as relative percentages to live cells of the untreated control samples. Under similar treatment conditions, cytarabine, was added to HL-60 cells at final concentrations of $0.01,0.02$ and $0.03 \mu \mathrm{M}$, and served as positive controls in each of the performed viability assay. The concentration of test compound leading to $50 \%$ reduction in cell viability $\left(\mathrm{IC}_{50}\right)$, compared to untreated control, was determined from the sigmoidal curve obtained by plotting the percentages of cell viability relative to the control versus logarithmic concentration of test compound using non-linear regression 


\section{Cellular Physiology Cell Physiol Biochem 2015;35:1958-1974 \begin{tabular}{l|l|l|l|l}
\hline DOI: 10.1159/000374004 & O 2015 S. Karger AG, Basel
\end{tabular} \begin{tabular}{l|l} 
and Biochemistry Published online: March 27, 2015 & www.karger.com/cpb \\
\hline
\end{tabular} \\ Saleh et al.: 5'-Cl Induces a Mitochondria Dependent Apoptosis in Leukemic Cells}

analysis of GraphPad Prism 6 (GraphPad Software, San Diego, California, USA). The $\mathrm{IC}_{50}$ for cytarabine (0.02 $\mu \mathrm{M}$ ) was previously determined in our laboratory in HL-60 cells (data not shown).

\section{Assays of caspase activities}

The activities of caspase-2, $-8,-9,-3 /-7$ and -6 in HL-60 cell lysates $(30 \mu \mathrm{g})$, obtained after treating with the proper concentration of 5 '-Cl or cytarabine for the desired time points in the presence or absence of $40 \mu \mathrm{M}$ of the general caspases inhibitor z-VAD-FMK, were determined spectrophotometricaly at 405 $\mathrm{nm}$ using a Spectra Max ${ }^{\mathrm{TM}}$ micro-plate reader (Molecular Devices, Sunnyvale, California, USA). The assays were performed by incubating the cell lysates with $0.2 \mathrm{mM}$ of the caspase-specific colorimetric tetrapeptide substrates, Ac-VDVAD-pNA (for caspase-2), Ac-IETD-pNA (for caspase-8), Ac-LEHD-pNA (for caspase-9), Ac-DEVD-pNA (for caspase-3/-7) or Ac-VEID-pNA (for caspase-6) for $1 \mathrm{~h}$ at $37^{\circ} \mathrm{C}$ as described by [20]. The increase in the absorbance at $405 \mathrm{~nm}$ which corresponds to the amount of p-nitroaniline (pNA) liberated from the peptide substrates was converted into units of enzyme activity using a standard curve generated with free pNA. One unit of caspase activity correspond to the amount of enzyme that will release $1 \mathrm{pmol}$ of pNA from $0.2 \mathrm{mM}$ of the different substrates per min. Lysates from HL-60 cells treated with 0.01 and 0.02 $\mu \mathrm{M}$ cytarabine were also used in these experiments as positive controls to validate the enzymatic assays.

\section{Evaluation of nuclear condensation by Hoechst 33342 staining}

$200 \mu \mathrm{L}$ of HL-60 cells were seeded at a concentration of $3 \times 10^{5}$ cells $/ \mathrm{mL}$ in a 96 -well plate and treated with different concentrations of 5 '-Cl or cytarabine. After $24 \mathrm{~h}$, the cells were collected by centrifugation and suspended in $100 \mu \mathrm{L}$ of $1 \%$ glutaraldehyde solution for $30 \mathrm{~min}$. Glutaraldehyde was then removed by centrifugation, and the cells were incubated with $4 \mu \mathrm{L}$ of the DNA-specific dye Hoechst $33342(1 \mathrm{mg} / \mathrm{mL})$. Morphological changes were observed under Evos $\mathrm{fl}^{\circledR}$ inverted digital fluorescent microscope (AMG, Mill Creek, Washington, USA).

\section{Analysis of apoptosis by flow cytometry}

The percentage of cells undergoing apoptosis after treatment with 5 '-Cl was determined using the Muse Annexin-V \& Dead Cell Assay kit ${ }^{\mathrm{TM}}$ (EMD Millipore Bioscience) according to the manufacturer's protocol. The kit utilizes a fluorescent dye (FITC) conjugated to Annexin-V to detect phosphatidylserine (PS) on the external membrane of apoptotic cells and 7-AAD (7-amino-actinomycin D) as a dead cells marker. 7-AAD is excluded from living healthy cells, as well as early apoptotic cells. Percentages of cells in early (Annexin- $\mathrm{V}^{+} / 7-\mathrm{AAD}^{-}$) and late stages of apoptosis (Annexin- $\mathrm{V}^{+} / 7-\mathrm{AAD}^{+}$) were determined using Muse ${ }^{\mathrm{TM}}$ Cell Analyzer. When z-VAD-FMK was used, cells were incubated with the desired concentration of this caspase inhibitor for $4 \mathrm{~h}$ before addition of $5^{\prime}-\mathrm{Cl}$. NAC $(500 \mu \mathrm{M})$ or PDTC $(50 \mu \mathrm{M})$ were added to cells only $30 \mathrm{~min}$ prior to incubation with the isoindigo compound. In all experiments, the solvent DMSO concentration was $\leq$ $0.05 \%$. Similar concentrations of DMSO were added to the control of untreated cells, and showed no effect on triggering apoptosis, when compared to the cultured HL-60 cells in the absence of DMSO. HL-60 cells were also treated with $0.02 \mu \mathrm{M}$ cytarabine as a positive control to validate the apoptosis results.

\section{Assessment of changes in mitochondrial transmembrane potential}

Measurement of changes in mitochondria membrane potential $\left(\Delta \Psi_{m}\right)$ was performed with the Muse MitoPotential Assay kit ${ }^{\mathrm{TM}}$ (EMD Millipore Bioscience). The assay utilizes the MitoPotential Dye, a cationic, lipophilic dye to detect changes in the mitochondrial membrane potential and 7-AAD as an indicator of cell death. High membrane potential drives accumulation of MitoPotential dye within inner membrane of intact mitochondria resulting in high fluorescence, while cells with depolarized mitochondria demonstrate a decrease in fluorescence. Therefore, this flow-cytomety-based assay differentiates 4 populations of cells; live cells with depolarized mitochondrial membrane: MitoPotential/7-AAD; live cells with intact mitochondrial membrane: MitoPotential ${ }^{+} / 7-\mathrm{AAD}^{-}$, dead cells with depolarized mitochondrial membrane: MitoPotential $^{+} / 7-\mathrm{AAD}^{+}$and dead cells with intact mitochondrial membrane: MitoPotential $/ 7-\mathrm{AAD}^{+}$. After treating with different concentrations of 5 '-Cl for $12 \mathrm{~h}$, or with $4.0 \mu \mathrm{M}$ of the compound for different periods, HL-60 cells were incubated with the fluorescent dyes and the percentage of depolarized cells (depolarized live + depolarized dead) were determined by Muse Cell Analyzer. Cells treated with cytarabine were used as internal positive control to validate the assay results.

\section{KARGER}




\section{Cellular Physiology Cell Physiol Biochem 2015;35:1958-1974

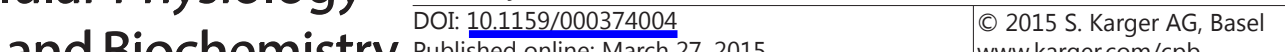 and Biochemistry Published online: March 27, $2015 \quad$ www.karger.com/cpb}

Quantitation of ATP levels in HL-60 treated cells

ATP contents were determined using the ATP Colorimetric/Fluorometric Assay Kit (BioVision, Inc.) according to the manufacturer's instructions. For time course $1 \times 10^{6}$ HL-60 cells were treated with $4.0 \mu \mathrm{M}$ 5 '-Cl, lysed, deproteinized and $10 \mu \mathrm{L}$ of the supernatant was added to $50 \mu \mathrm{L}$ of the reaction assay mixture. Absorbance was measured at OD $570 \mathrm{~nm}$ in a Spectra Max $^{\mathrm{TM}}$ micro-plate reader after 30 min incubation in dark.

Evaluation of ROS formation

Quantitative measurements of ROS, namely superoxide radicals in HL-60 cells undergoing oxidative stress after treatment with varying concentrations of $5^{\prime}-\mathrm{Cl}$ was performed using the Muse Oxidative Stress kit $^{\mathrm{TM}}$ (EMD Millipore Bioscience). The assay provides relative percentage of cells that are ROS negative and ROS positive on the Muse ${ }^{\mathrm{TM}}$ Cell Analyzer. After treating with $5^{\prime}-\mathrm{Cl}$ in the presence and absence of NAC $(500 \mu \mathrm{M})$ or PDTC $(50 \mu \mathrm{M})$, HL-60 cells were harvested, incubated with the oxidative stress reagent ${ }^{\mathrm{TM}}$ (dihydroethidium) and analyzed on the Muse ${ }^{\mathrm{TM}}$ Cell Analyzer according to the manufacturer's procedure.

Release of cytochrome c from mitochondria

Mitochondrial and cytosolic fractions from HL-60 cells treated with 5'-Cl were prepared by differential centrifugation at $4^{\circ} \mathrm{C}$ as described in our recent publication [20]. The release of cytochrome c from mitochondria into the cytoplasm of 5'-Cl-treated HL-60 cells was detected by probing the electrophoresed mitochondrial $(30 \mu \mathrm{g})$ or cytosolic $(50 \mu \mathrm{g})$ fractions, with an anti-cytochrome c antibody [(6H2): $\mathrm{mAb}$ 13561, Santa Cruz Biotechnology] as previously described [20].

Expression of bcl-2 gene

A semiquantitative reverse transcriptase polymerase chain reaction (RT-PCR) was carried out to determine the levels of $\mathrm{Bcl}-2$ mRNA expressions. The synthetic oligonucleotide primers used for $\mathrm{Bcl}-2$ are: (upstream) 5'-AGATGTCCAGCCAGCTGCAC-3' and (downstream) 5'-TGTTGA CTTCACTTGTGGCC-3' corresponding to a product size of $388 \mathrm{bp}$. The RT-PCR mixture (final volume of $20 \mu \mathrm{L}$ ) contained $3 \mu \mathrm{L}$ of cDNA, $10 \mu \mathrm{L}$ of Qiagen Multiplex PC Master Mix 2x (Qiagen, Germany) and 10 pmol of each primer. Amplification of $\beta$-actin, using the upstream primer $5^{\prime}$-GTGGGGCGCCCCAGGCACCA- $3^{\prime}$ and downstream oligonucleotide $5^{\prime}$-CTCCTTAATGTCACGCACGATTTC-3' , generating 516 bp product, was used as an internal control. Amplification was performed for $B c l-2$ and $\beta$-actin under the conditions described previously [21]. The density of visualized bands was quantitated by UN-SCAN-IT 7.0 gel and graph digitizing software.

Immunoprecipitation and western blot analyses

For immunoprecipitation, $25 \times 10^{6} \mathrm{HL}-60$ cells were treated with or without 5 '-Cl for $24 \mathrm{~h}$. Cells were lysed in ice-cold buffer containing $20 \mathrm{mM}$ Tris- $\mathrm{HCl} \mathrm{pH}$ 7.4, $150 \mathrm{mM} \mathrm{NaCl}, 1 \mathrm{mM}$ EDTA, 0.5\% NP-40, and protease inhibitors [ $1 \mu \mathrm{g} / \mathrm{mL}$ leupeptin, $1 \mu \mathrm{g} / \mathrm{mL}$ aprotinin, $1 \mu \mathrm{g} / \mathrm{mL}$ pepstatin A and $1 \mathrm{mM}$ PMSF]. After centrifugation at $14000 \mathrm{~g}$ for $20 \mathrm{~min}$ at $4^{\circ} \mathrm{C}$, lysates $(300 \mu \mathrm{g})$ were pre-cleared by incubating $\left(2 \mathrm{~h} \mathrm{at} 4^{\circ} \mathrm{C}\right)$ with $25 \mu \mathrm{l}$ protein A/G plus-agarose beads (Santa Cruz Biotechnology). Pre-cleared lysates were incubated overnight with $5 \mu \mathrm{g}$ of a specific polyclonal Bax antibody [(N-20): rAb 493, Santa Cruz Biotechnology]. Immunocomplexes were captured with $25 \mu \mathrm{L}$ protein $\mathrm{A} / \mathrm{G}$ plus-agarose, and the presence of Bcl- 2 in these complexes was determined by Western blot analysis.

Samples preparation and Western blot analysis were performed as previously described [20] and according to manufacturer's protocols. Primary antibodies against caspase-2 [(C2) Mouse mAb 2224], Caspase-8 [(1C12) Mouse mAb 9746], caspase-9 [(C9) Mouse mAb 9508], Cleaved Caspase-3 [(Asp175) (5A1E) Rabbit mAb 9664], cleaved caspase-6 [(Asp162) Antibody 9761], Phospho-Bcl-2 [antibody 2875] and PARP [antibody 9542] were obtained from Cell Signaling Technologies and used in 1:1000 dilution in PBST solution containing 3\% bovine serum albumin ( BSA). Primary antibodies against Bcl-2 [(C-2): $m A b$ 7382], Bcl- $X_{L}$ [(H-5): mAb 8392], Bax [(N-20): rAb 493] and Bak [(G-23): rAb 832] were purchased from Santa Cruz Biotechnology, and use in 1:1500 dilution PBST solution containing 5\% BSA. Secondary antibodies conjugated to horseradish peroxidase and Pierce ECL Plus substrate solution (ThermoScientific, Rockford, Illinois, USA) were used to generate signals and visualized by C-DiGit Blot Scanner (LI-COR Biotechnology - GmbH, Homburg, Germany). To confirm equal loading of proteins in gels, the blots were also immunoprobed with an antibody against $\alpha$-tubulin [(H-300): rAb 5546] or $\beta$-actin [(C4): mAb 47778] from Santa Cruz Biotechnology. The density of bands was quantitated using the UN-SCAN-IT 7.0 software. 
$\mathbf{A}$<smiles>CCn1cc(C(=O)O)c(=O)c2c3c(ccc21)NC(=O)C3=C1C(=O)Nc2ccc(Cl)cc21</smiles>

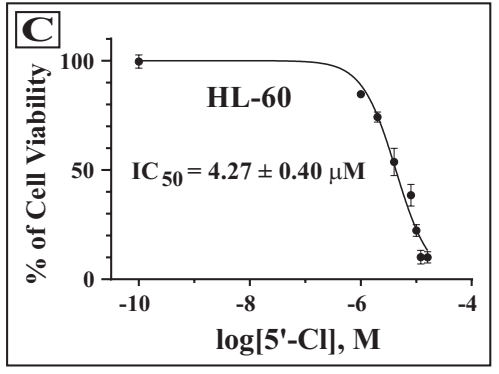

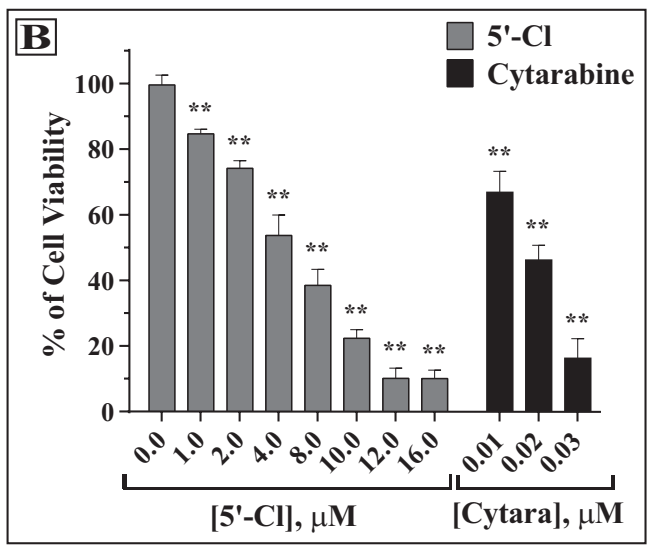

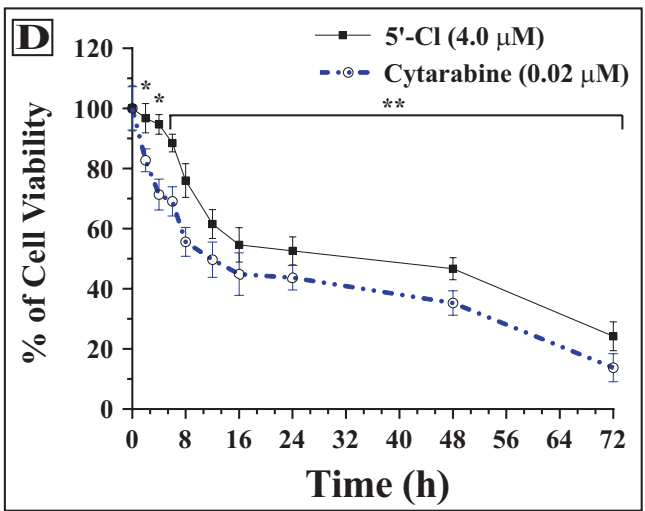

Fig. 1. 5'-Cl inhibits the growth of HL-60 cells in a dose and time-dependent manner. (A) Chemical structure of 5'-Cl [(E)-1-(5'-Chloro-2'-oxoindolin-3'-ylidene)-6-ethyl-2,3,6,9-tetrahydro-2,9-dioxo-1H-pyrrolo[3,2-f] quinoline-8-carboxylic acid]. (B) HL-60 cells were treated with increasing concentrations of 5 '-Cl (0.0 to $16.0 \mu \mathrm{M})$, or cytarabine $(0.0$ to $0.03 \mu \mathrm{M})$ for $24 \mathrm{~h}$. The percentage of cell viability in each sample was expressed relative to untreated control containing the carrier solvent DMSO. (C) The sigmoidal curve shown was obtained by plotting the mean percentages of viability versus logarithmic molar concentrations of 5 '-Cl, and the $\mathrm{IC}_{50}$ value was determined using a non-linear regression analysis of GraphPad Prism 6 software. (D) HL-60 cells were exposed to $4.0 \mu \mathrm{M} \mathrm{5}$ '-Cl or $0.02 \mu \mathrm{M}$ cytarabine for different time points ( 0 to $72 \mathrm{~h}$ ), and the viability was determined as describe in (B). The results shown represent the mean \pm SD of three independent experiments. $\left({ }^{* *}\right)$ For values that are significantly different and $(*)$ for statistically insignificant when compared to untreated control.

\section{Statistical analysis}

Data presented are the means \pm SD of results from a minimum of three independent experiments with similar patterns. Statistical analysis was performed using one-way ANOVA, and Tukey-Kramer multiplecomparison test was performed by using GraphPad Prism 6 software. A p $<0.05$ value was considered statistically significant.

\section{Results}

\section{5 '-Cl inhibits the proliferation of HL-60 cells}

To test the effect of 5'-Cl (Fig. 1A) on proliferation of an AML cell line, HL-60 cells were treated with increasing concentrations of the compound and analyzed for cell viability (Fig. 1B). Compared to the control group, the viability of the treated cells decreased from 84.70 $\pm 1.4 \%$ at a concentration of $1.0 \mu \mathrm{M}$ to $10.13 \pm 3.10 \%$ at $12.0 \mu \mathrm{M}$, with an $\mathrm{IC}_{50}$ of $4.27 \pm 0.40$ $\mu \mathrm{M}$ (Fig. 1C). 5'-Cl also inhibited the growth of HL-60 in a time-dependent manner (Fig. 1D). 


\section{Cellular Physiology Cell Physiol Biochem 2015;35:1958-1974 \begin{tabular}{l|l}
\hline DOI: 10.1159/000374004 & O 2015 S. Karger AG, Basel
\end{tabular} and Biochemistry Published online: March 27, 2015 www.karger.com/cpb

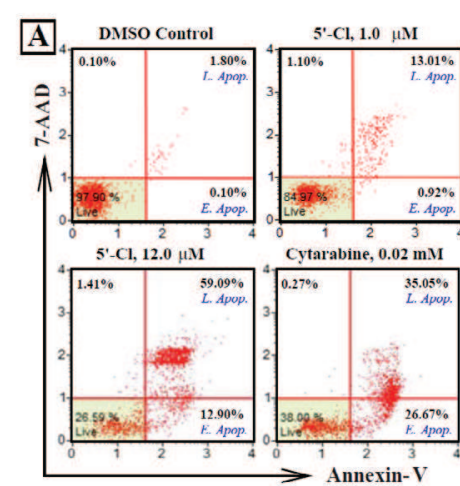

B

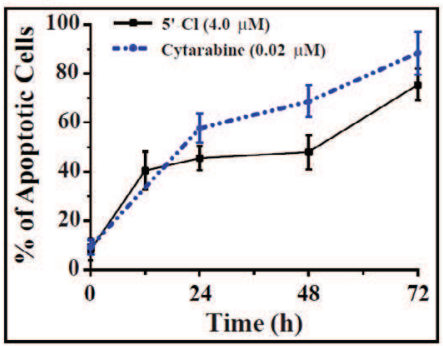

C

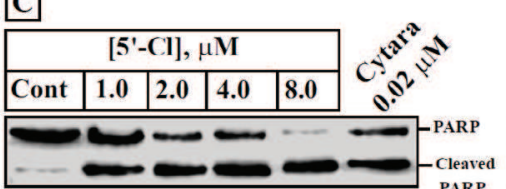

D
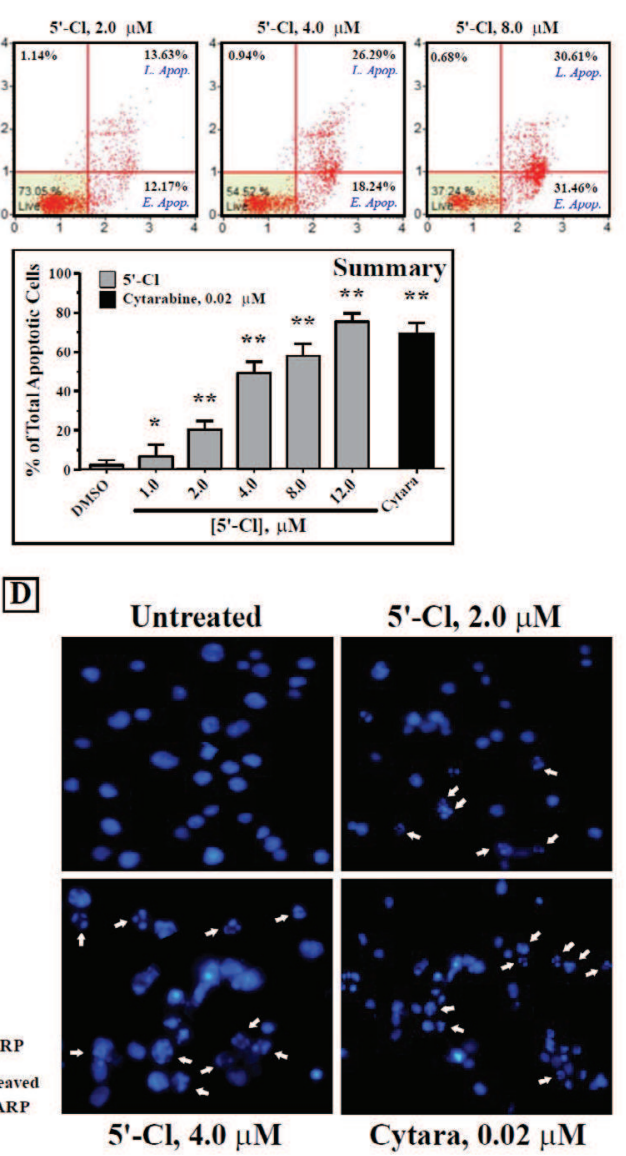

Fig. 2. The growth inhibitory effect of 5 '-Cl on HL-60 cells is mediated by apoptosis. (A) HL-60 cells were treated with varying concentrations of $5^{\prime}-\mathrm{Cl}(0.0$ to $12.0 \mu \mathrm{M})$ or with $0.02 \mu \mathrm{M}$ cytarabine for $24 \mathrm{~h}$ and apoptosis was analyzed by a flow cytometer after staining with FITC-annexin-V/7-AAD. The scattered blots showing the percentages of early and late apoptosis are indicated for one experiment. The graph represents the summary mean percentages \pm SD of apoptosis (early and late apoptosis) of three independent experiments. (B) HL-60 cells were treated with $4.0 \mu \mathrm{M}$ 5'-Cl or $0.02 \mu \mathrm{M}$ cytarabine for different periods ( 0 to $72 \mathrm{~h}$ ) and apoptosis was analyzed as described above. All values in (B) and $\left(^{* *}\right)$ marked in (A) are significantly different. $\left({ }^{*}\right)$ For statistically insignificant when compared to untreated control. (C) Western blot analysis of PARP of HL-60 lysates $(50 \mu \mathrm{g})$ obtained from cells treated with various concentrations of 5 '-Cl or $0.02 \mu \mathrm{M}$ cytarabine. The full length and cleaved bands of PARP are indicated. (D) HL-60 cells treated with proper concentration of 5 '- $\mathrm{Cl}$ or cytarabine, as indicated on top of each photograph, for $24 \mathrm{~h}$ and stained with Hoechst 33342 . The arrow heads show the condensation of chromatin material and fragmentation of nuclei in apoptotic cells.

A significant reduction in cell viability $(\sim 12 \%$, compared to untreated control) was seen after $6 \mathrm{~h}$ incubation with $4.0 \mu \mathrm{M}$ of $5^{\prime}-\mathrm{Cl}$ and reached $\sim 76 \%$ after $72 \mathrm{~h}$.

The antiproliferative effect of $5^{\prime}$-Cl is mediated by apoptosis

As shown in Fig. 2A, a dose-dependent increase in annexin- $\mathrm{V}^{+}$cells was observed after treatment with $5^{\prime}$-Cl for $24 \mathrm{~h}$. Quantitative measurement showed a proportional increase in the percentage of apoptotic HL-60 cells from $8.90 \pm 5.31 \%$ to $75.2 \pm 4.24 \%$ after treatment with $1.0 \mu \mathrm{M}$ to $12.0 \mu \mathrm{M}$ of 5 '-Cl. In addition, 5 '-Cl induced a time-dependent increase in apoptotic cells (from $7.4 \pm 4.38 \%$ to $75.50 \pm 6.36 \%$ ) after treatment with $4.0 \mu \mathrm{M}$ for $72 \mathrm{~h}$ (Fig. $2 \mathrm{~B})$. Interestingly, neither increasing the concentration of $5^{\prime}-\mathrm{Cl}$ to $12.0 \mu \mathrm{M}\left(\sim 3\right.$-fold the $\left.\mathrm{IC}_{50}\right)$

\section{KARGER}




\section{Cellular Physiology Cell Physiol Biochem 2015;35:1958-1974 \begin{tabular}{l|l} 
DOI: 10.1159/000374004 & $\begin{array}{l}\text { C } 2015 \mathrm{~S} \text {. Karger AG, Basel } \\
\text { www.karger.com/cpb }\end{array}$ \\
\hline
\end{tabular}}

nor extending the exposure time at this concentration to $72 \mathrm{~h}$ caused a significant increase in the percentage of necrotic cells (annexin- $\mathrm{V}^{-} / 7-\mathrm{AAD}^{+}$, data not shown), suggesting that most of its antiproliferative activity is mediated by apoptosis. As an evidence of late apoptosis events, 5 '-Cl was found to trigger PARP cleavage (Fig. 2C) and condensation of the chromatin material and fragmentation of nuclei (Fig. 2D) in a dose-dependent manner. These findings indicate that the $5^{\prime}$-Cl-induced cell death in HL-60 cells is primarily through apoptosis.

\section{Role of caspases in 5'-Cl-induced apoptosis}

To further characterize the 5'-Cl-triggered apoptosis in HL-60 cells, we examined its effect on activation of caspases. 5 '- $\mathrm{Cl}$ was found to trigger a dose-dependent increase in the specific activities of the initiator caspase-2, -8 and -9 , and the effector caspase- $3 /-7$ and -6 reaching mean peak values $(0.99 \pm 0.18,2.28 \pm 0.24,1.97 \pm 0.34,2.37 \pm 0.52$ and $0.89 \pm$ $0.19 \mathrm{pmol} \mathrm{pNA} / \mathrm{min} / \mathrm{mg}$ protein, respectively, Fig. 3A). Processing of caspase-2, -8 and -9 were demonstrated by the decrease in the levels of procaspases and the appearance of their corresponding cleaved products, while caspase- 3 and -6 by the increase in the small subunits of the active enzymes (Fig. 3B). The processing of caspases coincided with their enzymatic activity and increased after exposing the cells to 5 '-Cl in a dose-dependent manner.

To examine if $5^{\prime}$-Cl-induced apoptosis in HL-60 cells is completely dependent on caspases activation, we used $20.0 \mu \mathrm{M}$ and $40.0 \mu \mathrm{M}$ of the general caspase inhibitor z-VADFMK. In comparison to cells treated with 5 '-Cl alone, z-VAD-FMK significantly reduced the compound-induced apoptosis from $56.13 \pm 5.42 \%$ to $41.10 \pm 6.0 \%$ (with $20.0 \mu \mathrm{M} \mathrm{z}$-VADFMK) and to $35.06 \pm 7.0 \%$ (with $40.0 \mu \mathrm{M} \mathrm{z}$-VAD-FMK). These corresponded to $\sim 27 \%$ and $\sim 38 \%$ relief of apoptosis, respectively (Fig. 3C). Importantly, the presence of $40.0 \mu \mathrm{M}$ of z-VAD-FMK was adequate to completely inhibit the 5'-Cl-induced activation of all caspases shown in Fig. 3A. Therefore, further increase in the concentration of z-VAD-FMK did not show additional apoptosis recovery effects (data not shown). These results indicate that 5 '-Cl-induced apoptosis, at least in part, is dependent on caspase activation.

Mitochondrial stress is an important event of the 5'-Cl-induced apoptosis

The effect of 5 '- $\mathrm{Cl}$ on depolarization of the mitochondrial membranes (loss of $\Delta \Psi \mathrm{m}$ ) was measured after exposing HL-60 cells to $5^{\prime}$-Cl. We observed a dose-dependent increase in the mean percentages of depolarization from $11.33 \pm 2.64 \%$ in the untreated control to $43.97 \pm 3.26 \%$ and $52.87 \pm 7.04 \%$ in the presence of $4.0 \mu \mathrm{M}$ and $8.0 \mu \mathrm{M}$ of the drug, respectively. Interestingly, cells treated with $40.0 \mu \mathrm{M}$ of z-VAD-FMK prior to addition of 4.0 $\mu \mathrm{M}$ of the test compound resulted only in an approximately $24 \%$ recovery of depolarization (depolarization was reduced from $43.97 \pm 3.26 \%$ to $33.63 \pm 4.12 \%$ ), when compared to control cells treated with 5 '-Cl alone. Similarly, $4.0 \mu \mathrm{M}$ of 5'-Cl induced a time-dependent increase in the percentages of depolarized cells. A significant change in the mitochondria membrane potential was evident after $4 \mathrm{~h}$ incubation with the compound $(21.80 \pm 3.68 \%)$ and reached the peak value $(54.10 \pm 6.51 \%)$ after $16 \mathrm{~h}$ (Fig. 4B). The $5^{\prime}$-Cl-induced depolarization of mitochondria also interferes with ATP synthesis in the treated cells. As shown in Fig. 4C, 5'$\mathrm{Cl}$ induced a time-dependent decrease in the relative levels of cellular ATP. The mean level of ATP decreased to $75.30 \pm 7.10$ and $61.30 \pm 5.96 \%$ after $12 \mathrm{~h}$ and $24 \mathrm{~h}$ incubation, respectively.

\section{5'-Cl triggers generation of ROS in HL-60 cells}

As shown in Fig. 5A, the cell population with positive ethidium salt-derived fluorescence (ROS ${ }^{+}$cells) increased in a dose-dependent fashion. The mean percentage of ROS ${ }^{+}$HL-60 cells increased from $22.63 \pm 2.27 \%$ to $63.36 \pm 6.60 \%$ after incubation with $2.0 \mu \mathrm{M}$ to 8.0 $\mu \mathrm{M}$ of 5 '-Cl. Pre-incubation of HL-60 cells with either the ROS scavenger NAC $(500 \mu \mathrm{M})$ or PDTC $(50 \mu \mathrm{M})$ caused $\sim 61 \%(47.62 \pm 5.28 \%$ to $18.40 \pm 2.7 \%)$ and $\sim 55 \%(47.62 \pm 5.28$ to $21.60 \pm 3.9 \%$ ) reduction in $\mathrm{ROS}^{+}$cells induced by $4.0 \mu \mathrm{M} \mathrm{5}$ '-Cl, respectively (Fig. $5 \mathrm{~A}$ ). Further increase in the concentrations of either antioxidants interfered with the cell growth and did not show additional inhibition of ROS formation triggered by $5^{\prime}-\mathrm{Cl}$ (data not shown). The 5 '-Cl-stimulated ROS formation was also a time-dependent. A significant increase in ROS $^{+}$ 


\section{Cellular Physiology Cell Physiol Biochem 2015;35:1958-1974 \begin{tabular}{l|l}
\hline DOI: 10.1159/000374004 & O 2015 S. Karger AG, Basel
\end{tabular}}

and Bion et al.: $5^{\prime}$-Cl Induces a Mitochondria Dependent Apoptosis in Leukemic Cells

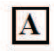
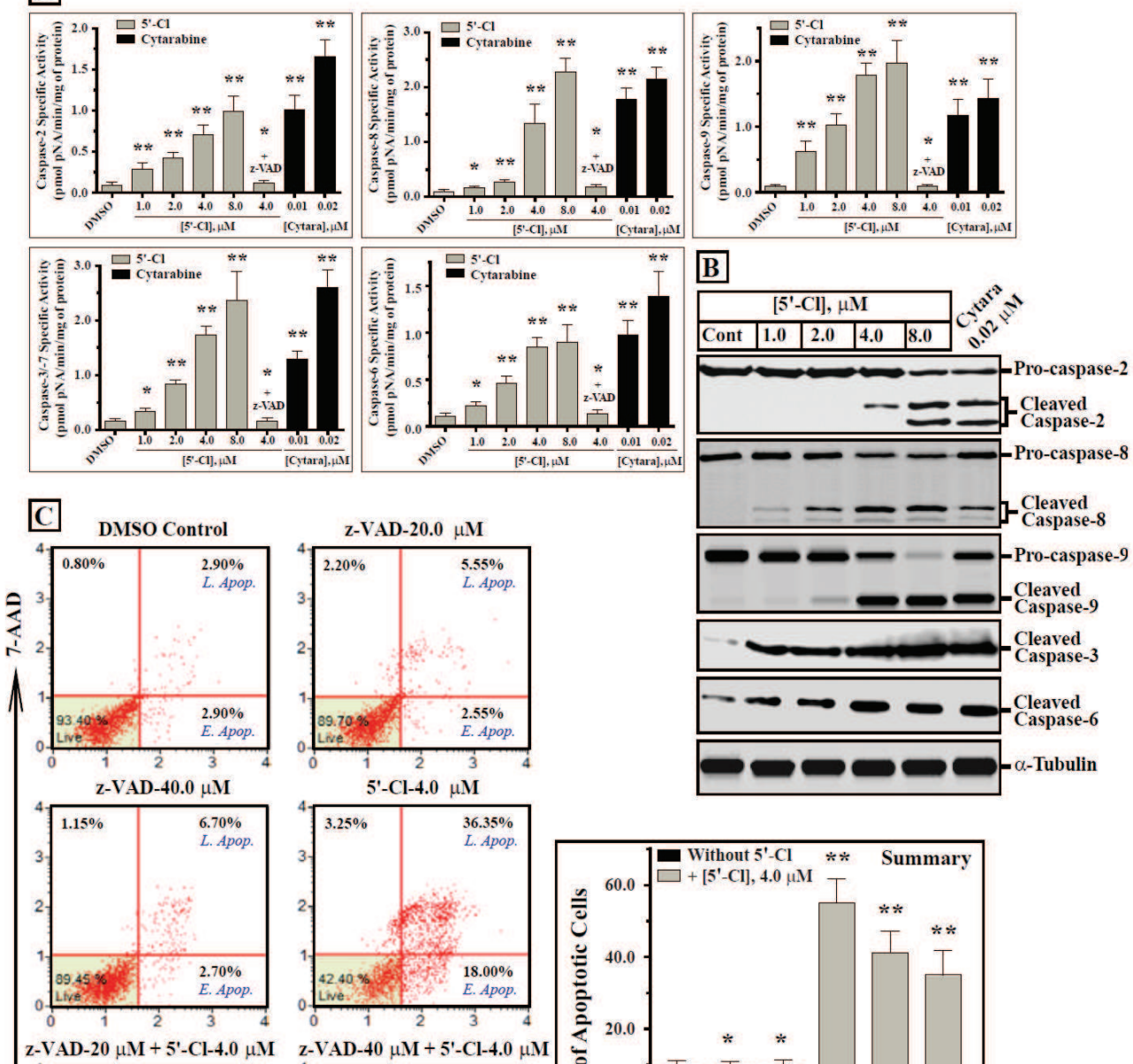

z-VAD-20 $\mu \mathrm{M}+5$ '-Cl-4.0 $\mu \mathrm{M}$
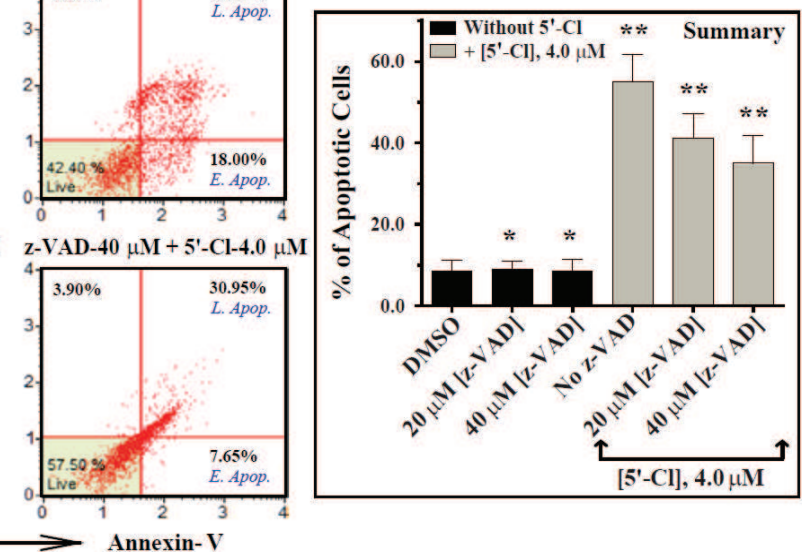

Fig. 3. 5'-Cl triggers a caspase-dependent and caspase-independent apoptosis in HL-60 cells. (A) Extracts (30 $\mu \mathrm{g}$ proteins) from cells treated with different concentrations of 5 '-Cl or cytarabine for 24 were analyzed for caspase-2, -8, -9, -3/-7 and -6 catalytic activities using their specific colorimetric tetrapeptide substrates. The specific enzyme activities, which represent the mean \pm SD of three independent experiments, were measured as described in the methods. The cells were also treated with the general caspase inhibitor z-VADFMK $4 \mathrm{~h}$ prior to addition of $4.0 \mu \mathrm{M}$ of 5 - $\mathrm{Cl}$ as negative controls. (B) Whole cell extracts $(50 \mu \mathrm{g})$, obtained from HL-60 cells after treatment with varying concentrations of 5 '-Cl or cytarabine for 24 , were analyzed by Western blotting with antibodies against the initiator caspase-2, -8 and -9 , and effector caspase-3 and -6 , respectively. The unprocessed forms of procaspase-2, -8 and -9 , and their respective cleavage products of the active enzymes are indicated. The processed form (small subunit) of caspase- 3 and -6 are also marked. The same membranes were also probed with an antibody against $\alpha$-tubulin as a loading control. (C) HL-60 cells were exposed to $4.0 \mu \mathrm{M} \mathrm{5}$ '-Cl for $24 \mathrm{~h}$ in the presence and absence of $20 \mu \mathrm{M}$ or $40 \mu \mathrm{M} \mathrm{z}$-VAD-FMK, and apoptosis was analyzed after staining with FITC-annexin-V/7AAD as described in Figure 2A. The scattered apoptosis blots represent one experiment. The graph represents the summary mean percentages \pm SD of apoptosis (early and late apoptosis) of three independent experiments. (**) For values that are significantly different and $(*)$ for statistically insignificant when compared to untreated control. 


\section{Cellular Physiology \\ Cell Physiol Biochem 2015;35:1958-1974 and Biochemistry

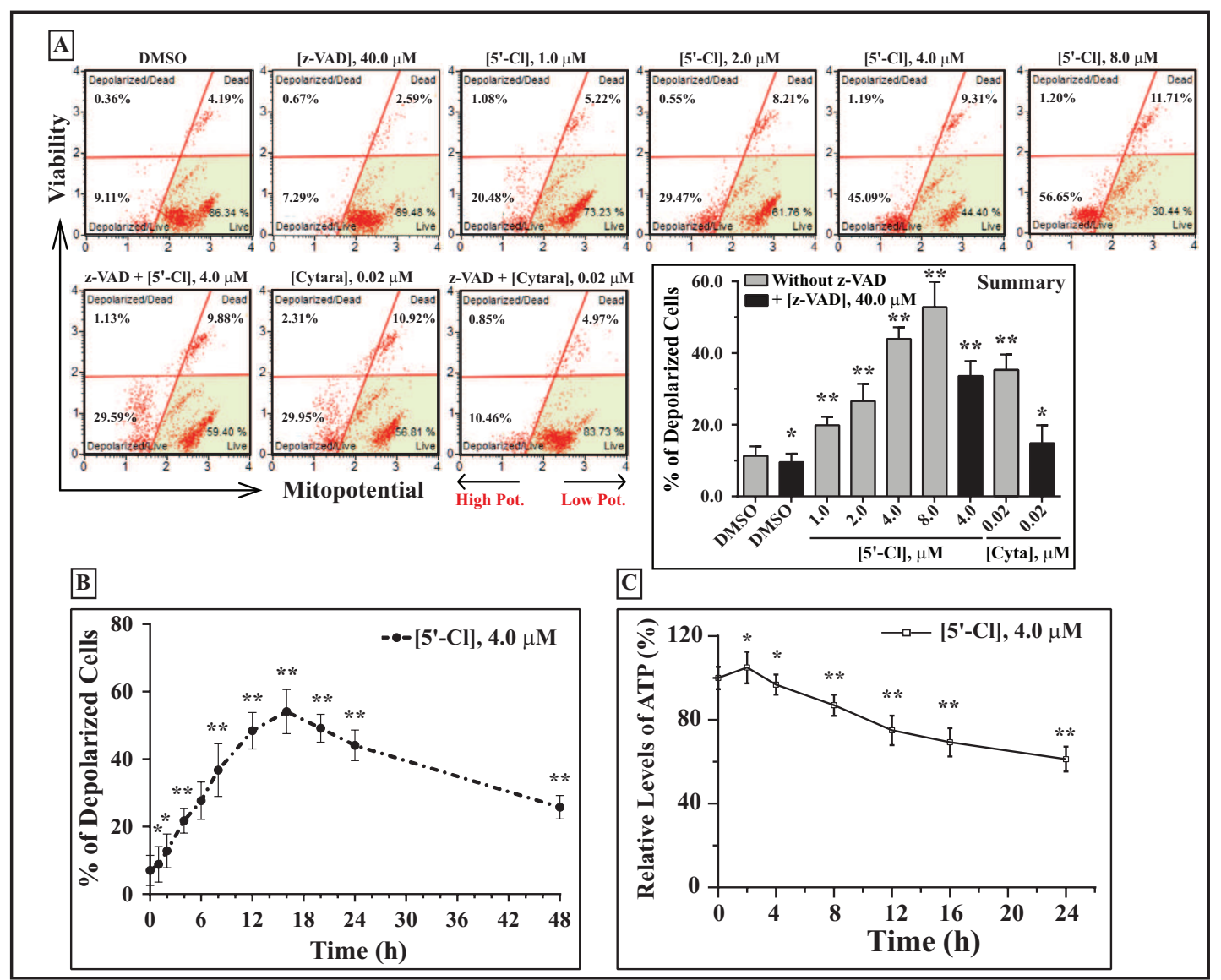

Fig. 4. 5'-Cl induces dysfunctioning of mitochondria in HL-60 cells that is mostly independent from activation of caspases. (A) HL-60 cells were treated with varying concentrations of 5'-Cl $(0.0$ to $8.0 \mu \mathrm{M})$ or $0.02 \mu \mathrm{M}$ cytarabine in the presence and absence of $40 \mu \mathrm{M}$ z-VAD-FMK for $12 \mathrm{~h}$. after incubation, cells were treated with the Muse Mitopotential reagent ${ }^{\mathrm{TM}}$ and the depolarization of the inner mitochondrial membrane was evaluated by the Muse ${ }^{\mathrm{TM}}$ flow cytometer. The scattered blots showing the percentages of live and dead depolarized cells are indicated for one experiment. The graph represents the summary mean percentages \pm SD of total depolarization for three independent experiments. (B) Similarly, HL-60 were exposed to $4.0 \mu \mathrm{M} \mathrm{5}$ '-Cl for increasing intervals and depolarization was assessed as described above. (C). Hl-60 cells were exposed to $4.0 \mu \mathrm{M} \mathrm{5}$ '-Cl for increasing periods and the level of ATP, relative to the untreated control was determined spectrophotometrically as described in the methods. All the data shown represent the mean \pm SD of three independent experiments. $\left({ }^{* *}\right)$ For values that are significantly different and $\left({ }^{*}\right)$ for statistically insignificant when compared to their proper untreated control.

cells occurred as early as 3-4h ( $\sim 2$ - to $\sim 3$-fold above baseline) and reached a peak level between $12 \mathrm{~h}$ to $16 \mathrm{~h}$ after treatment ( $\sim 5$ - to $\sim 6$-fold, Fig. 5B).

To determine whether the generation of ROS contributes to 5 '-Cl-induced cell death, we evaluated the mitochondrial membrane potential and apoptosis in HL-60 cells treated with the ROS scavengers prior to addition of the compound. In contrast to cells treated with 5'-Cl alone, the percentage of depolarization decreased from $45.3 \pm 3.7 \%$ to $24.9 \pm 3.4(\sim 45 \%$ recovery) in the presence of NAC and to $22.5 \pm 2.9 \%$ ( $\sim 50 \%$ recovery) in cells pre-incubated with PDTC prior to addition of 5'-Cl (Fig. 5C). Similarly, the percentages of apoptotic cells decreased to $31.7 \pm 4.7 \%$ ( $\sim 6 \%$ recovery $)$ and $28.6 \pm 3.6 \%$ ( $~ 51 \%$ recovery $)$ in the presence of NAC or PDTC, respectively, compared to the control treated with 5 '-Cl alone $(58.2 \pm 4.9 \%$, Figure 5D). Interestingly, under similar treatment conditions, addition of z-VAD-FMK with the ROS scavenger caused only insignificant decrease in the percentages of mitochondria depolarization induced by 5 '-Cl over control cells treated with either NAC or PDTC and the 


\section{Cellular Physiology Cell Physiol Biochem 2015;35:1958-1974

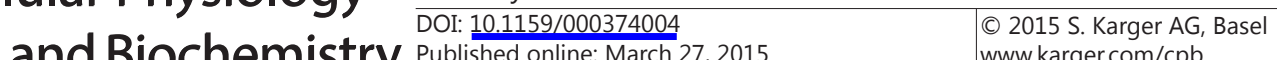 and Biochemistry Published online: March 27, $2015 \quad$ www.karger.com/cpb}

Fig. 5. Generation of ROS triggered by $5^{\prime}-\mathrm{Cl}$ contributes substantially to dysfunctioning of mitochondria and apoptosis is HL-60 cells. (A) HL-60 cells were treated with increasing concentrations of $5^{\prime}-\mathrm{Cl}(0.0$ to $8.0 \mu \mathrm{M}$ ) in the presence or absence $500 \mu \mathrm{M}$ NAC or $50 \mu \mathrm{M}$ PDTC. After incubation with the drug for $12 \mathrm{~h}$, the formation of ROS was measured using the Muse flow cytometry-based oxidative stress assay $^{\mathrm{TM}}$ as described under the methods. The histograms show the percentages of ROS (M1) and $\mathrm{ROS}^{+}$(M2) for one experiment. The graph represents the summary mean percentages \pm SD of $\mathrm{ROS}^{+}$cells from three independent experiments. (B) Similarly, HL-60 cells were treated with 4.0 $\mu \mathrm{M}$ 5'-Cl or $0.02 \mu \mathrm{M}$ cytarabine for different time points and the mean percentages \pm SD of ROS $^{+}$ cells were determined as
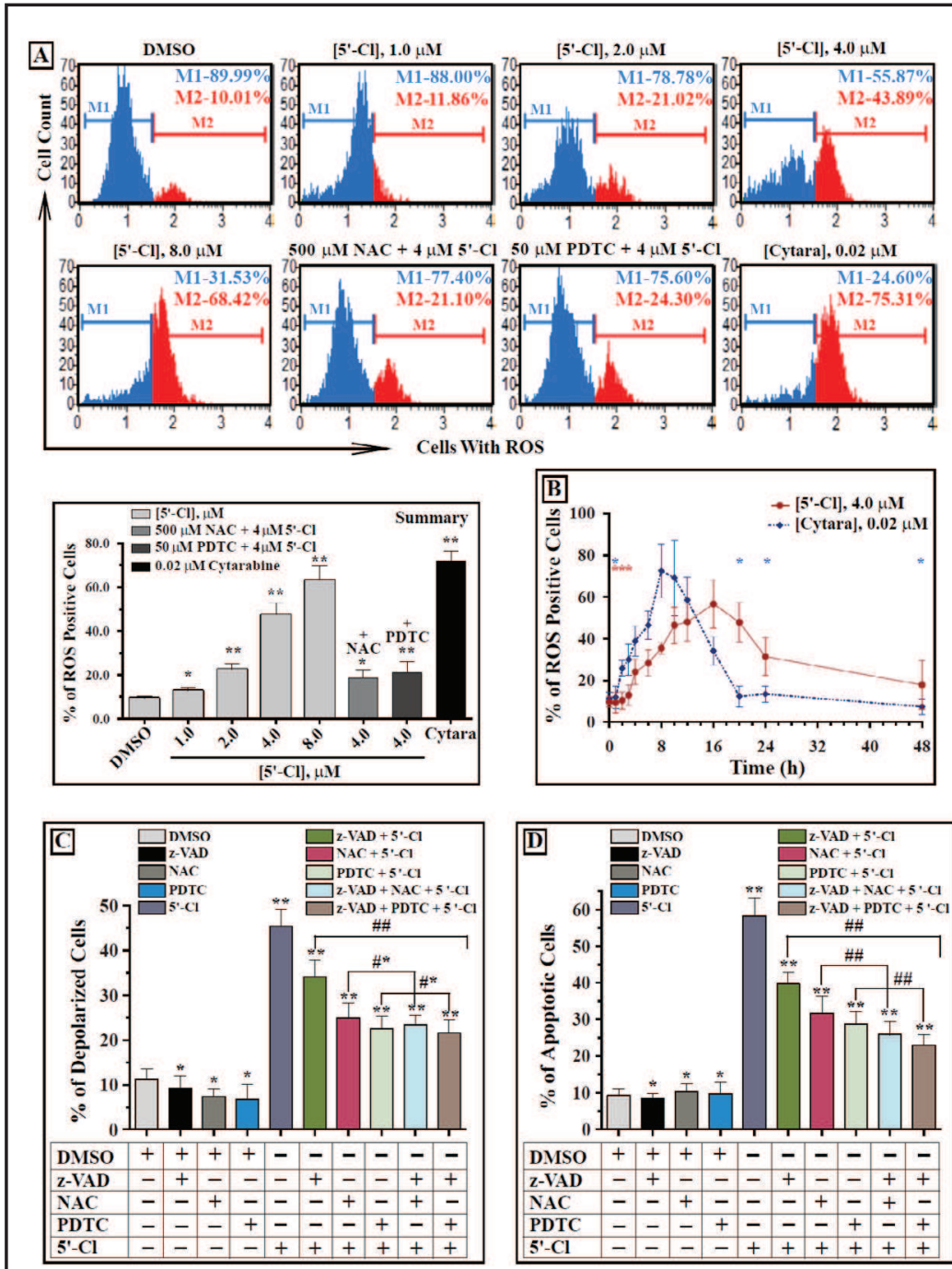

described above in three independent experiments. (C \& D) HL-60 cells were treated with $4.0 \mu \mathrm{M} \mathrm{5'-Cl}$ in the presence and absence of either ROS scavengers, z-VAD-FMK or combinations of the scavenger and $\mathrm{z}$-VAD-FMK as indicated at the bottom of each graph. After treatment for $12 \mathrm{~h}$, the cells were analyzed for mitochondria depolarization (C) and Apoptosis (D) as described in Figure 3A and Figure 2A, respectively. All the data shown represent the mean \pm SD of three independent experiments. (** \& \#\#) For values that are significantly different and $\left(* \& \#^{*}\right)$ for statistically insignificant when compared to their indicated proper controls.

test compound (Fig. 5C). On the other hand, the same combination of inhibitors showed a significant reduction in HL-60 cell death, suggesting a synergistic effect of both caspase activation and ROS formation in 5'-Cl-induced apoptosis (Fig. 5D). The presence of either NAC/z-VAD-FMK or PDTC/z-VAD-FMK caused 57\% (58.20 $\pm 4.9 \%$ to $24.50 \pm 3.9 \%)$ and $\sim 63 \%(58.20 \pm 4.9 \%$ to $21.12 \pm 3.1 \%)$ reduction in apoptosis in HL-60 cells, respectively, whereas individually, z-VAD-FMK, NAC and PDTC caused $\sim 32 \%, \sim 46 \%$ and $\sim 51 \%$ decrease in apoptosis, respectively, compared to cells treated with 5 '-Cl alone.

5 '-Cl modulates the expression and function of Bcl-2

Our immunoblotting results showed that exposure of HL-60 to 5 '-Cl decreased the expression levels of the antiapoptotic protein Bcl-2 in a dose-dependent manner (Fig. 6A). 


\section{Cellular Physiology Cell Physiol Biochem 2015;35:1958-1974

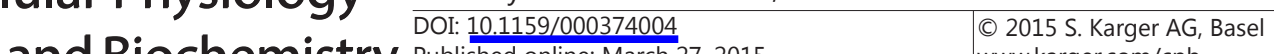 and Biochemistry Published online: March 27, 2015 www.karger.com/cpb \\ Saleh et al.: 5'-Cl Induces a Mitochondria Dependent Apoptosis in Leukemic Cells}

Fig. 6. 5'-Cl modulates the expression of $\mathrm{Bcl}-2$ and its association with Bax protein, and triggers the release of mitochondrial cytochrome c to the cytosol. (A) $50 \mu \mathrm{g}$ lysate proteins, from HL-60 cells treated without or with increasing concentrations of 5 '-Cl, were immunoblotted with antibodies against Bcl2, phosphor-Bcl-2, Bcl- $\mathrm{X}_{\mathrm{L}}$, Bax, Bak and $\alpha$-tubulin. (B \& C) Densitometric scanning for the intensity levels of Bcl-2 (relative to untreated control), obtained from Western blotting of the protein in HL-60 cells treated with different concentrations of 5 '-Cl for $24 \mathrm{~h}$ (B), or with $4.0 \mu \mathrm{M}$ of the compound for various periods (C). The values represents the mean relative band densities $\pm \mathrm{SD}$ of two independent experiments. (D) Semiquantitative RT-PCR for Bcl-2 mRNA obtained from untreated or treated cells with 5 '-Cl for
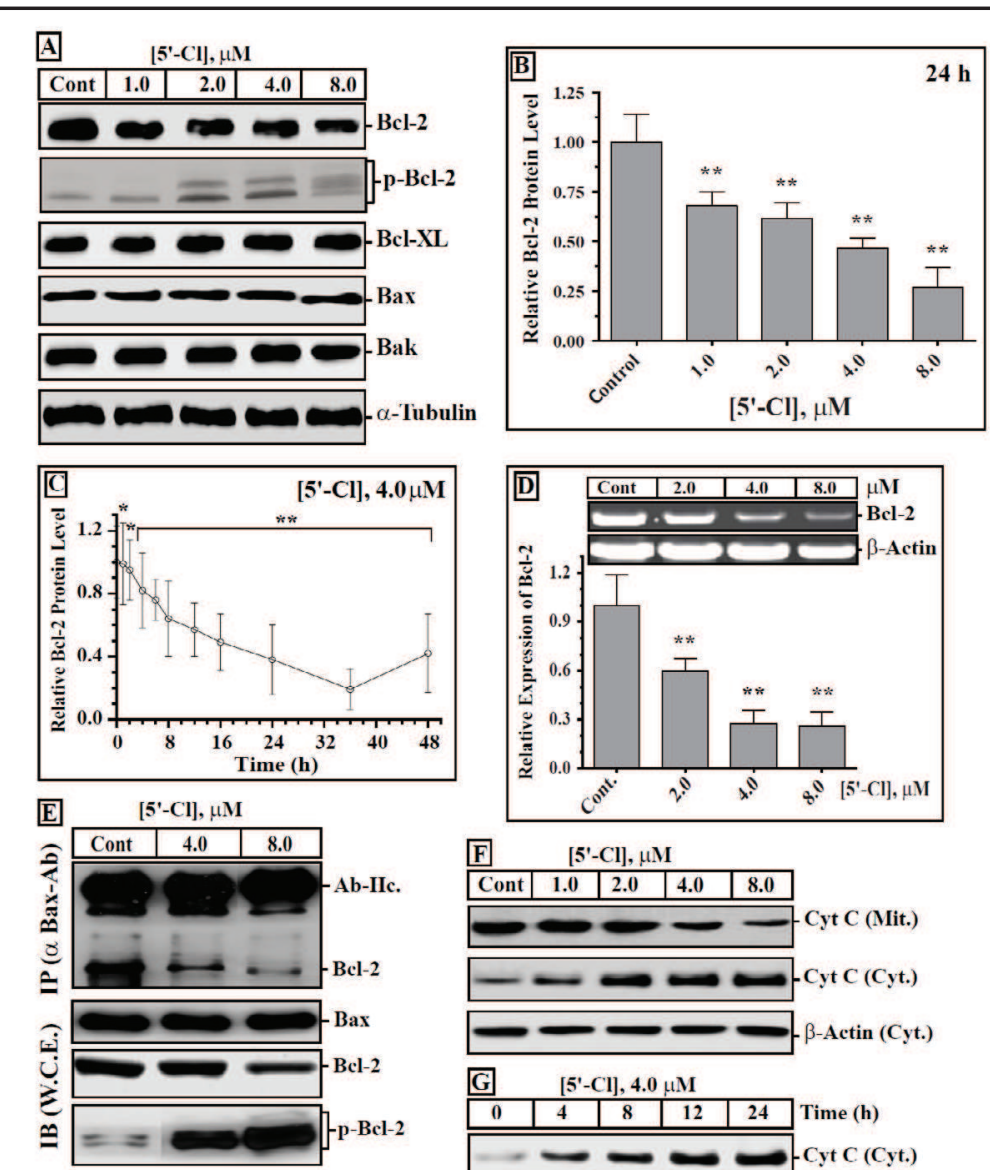

F

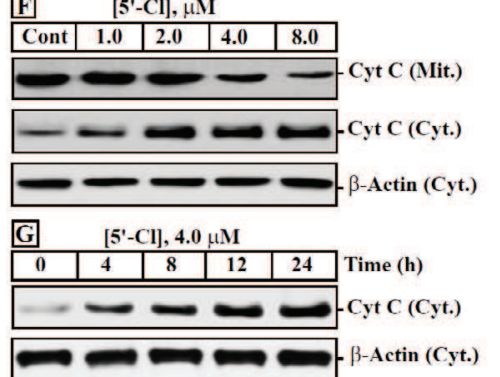

$24 \mathrm{~h}$. The final amplification products were electrophoresed and photographed. The density of visualized bands (from two independent trials) were quantitated and the values were normalized to $\beta$-actin intensity levels. $\left({ }^{* *}\right)$ For values that are significantly different and $\left({ }^{*}\right)$ for statistically insignificant when compared to their proper untreated control. (E) Bax was immunoprecipitated from lysates (300 $\mu \mathrm{g}$ ), obtained from untreated and treated HL-60 with 5 '- $\mathrm{Cl}$, and the presence of $\mathrm{Bcl}-2$ in these complexes (IP) was visualized by Western blot analysis. The heavy chain of Bax antibody (Ab-Hc.) is also shown. Immunoblotting (IB) for Bax, Bcl-2 and phosho-Bcl-2 from $50 \mu \mathrm{g}$ protein of the whole cell extracts (WCE) are shown to verify that the reduced amount of Bcl-2 co-immunoprecipitated with Bax is due to loss of their protein-protein interactions, rather than variations in the protein levels. (F \& G) Mitochondrial (Mit., $30 \mu \mathrm{g}$ ) and cytosolic (Cyt., $50 \mu \mathrm{g}$ ) fractions were prepared from HL-60 cells treated with 5'-Cl and immunoblotted with a specific anti-cytochrome c antibody.

Quantification of Bcl-2 revealed that the protein relative levels gradually decreased with increasing concentrations of $5^{\prime}-\mathrm{Cl}$ and reached approximately $27 \%(0.27 \pm 0.11)$ the amount of untreated control after exposure to $8.0 \mu \mathrm{M}$ of the compound, (Fig. 6B). In addition, serial electrophoretic analyses of Bcl-2 in HL-60 cells treated with $4.0 \mu \mathrm{M} \mathrm{5} 5^{\prime}-\mathrm{Cl}$ clearly showed a decrease in the level of Bcl-2 after $4 \mathrm{~h}$ of incubation ( $\sim 82 \%$, relative to the control), and reached the lowest relative level at $36 \mathrm{~h}(\sim 19 \%)$. However, the relative level of the protein increased to approximately $\sim 42 \%$ after $48 \mathrm{~h}$ of treatment. On the other hand, the amount of the proapoptotic proteins Bax and Bak and antiapoptotic Bcl- $X_{L}$ were not changed in the same experiments (Fig. 5A). Furthermore, our results indicate that the decreased level of Bcl2 protein in 5 '-Cl-treated cells is due to the effect of the compound on gene expression rather than its post-translational degradation. Semiquantitative analysis of mRNA by RT-PCR from cells treated with $5^{\prime}-\mathrm{Cl}$ showed that the relative expression level of $\mathrm{Bcl}-2$ was suppressed by 


\section{Cellular Physiology Cell Physiol Biochem 2015;35:1958-1974

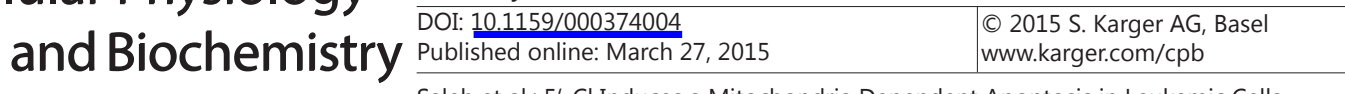

a magnitude of $\sim 4$-fold in HL-60 cells treated with $8.0 \mu \mathrm{M}$, compared to untreated control (Fig. 6D).

Interestingly, our Western blots showed that treating HL-60 cells with 5 '-Cl caused an increase in the levels of Bcl-2 phosphorylation. Clearly, two-bands of phosho-Bcl-2 were evident after exposing the cells to $2.0 \mu \mathrm{M}$, and three-bands of the protein were visible after incubation with $8.0 \mu \mathrm{M}$ of 5'-Cl (Fig. 6A). We further questioned whether 5'-Cl-induced hyperphosphorylation of Bcl-2 would affect its association with Bax. As shown in Fig. 6E, the level of Bcl-2 co-immunoprecipitated with Bax from 5'-Cl-treated cells was distinctly lower than the one from untreated cells. The finding that the association between $\mathrm{Bcl}-2$ and Bax is highly dependent on the dose of 5 '-Cl, coincided with same concentration-dependent hyperphosphorylation of Bcl-2 shown in Fig. 6A. The reciprocal immunoprecipitation experiment, using an anti-Bcl-2 antibody, also showed a substantial concentration-dependent reduction in the level of the co-immunoprecipitated Bax in 5'-Cl-treated cells, compared to the immunocomplex from untreated cells (data not shown).

\section{5'-Cl induces release of cytochrome c to the cytoplasm of $\mathrm{HL}$-60 cells}

We further investigated the ability of $5^{\prime}$-Cl to trigger the release of cytochrome c from the mitochondria into the cytosol of HL- 60 cells. Cytosolic cytochrome c was increased by varying the concentration (Fig. 6F) and exposure time (Fig. 6G) to 5'-Cl in $\mathrm{HL}-60$ cells, and the levels of cytochrome $c$ that remained in the mitochondria was observed to decrease concomitantly (Fig. 6G). In comparison to the untreated control, increasingly detectable difference in the level of cytosolic cytochrome c was apparent after exposing the cells to $1.0 \mu \mathrm{M}$ to $8.0 \mu \mathrm{M}$ and from 4 to $24 \mathrm{~h}$ after incubating with $4.0 \mu \mathrm{M}$ of $5^{\prime}-\mathrm{Cl}$. The release of cytochrome $\mathrm{c}$ results coincide with the demonstrated 5 '-Cl dose and time-dependency disturbances of mitochondria and induction of apoptosis.

\section{Discussion}

Cell death may occur by many ways such as necrosis, autophagy, mitotic catastrophe, senescence and apoptosis [22]. For 5'-Cl-induced cell death, apoptosis seems to be the primary death mechanism. This is supported by the following findings: first, 5 '-Cl-treated HL60 cells showed the morphological aspects associated with early and late apoptotic events. Second, 5 '-Cl induced activation of the initiator and terminal caspases that typically mediate and execute apoptotic cell death. Third, $5^{\prime}-\mathrm{Cl}$ caused condensation and fragmentation of HL-60 nuclei. Finally, 5'-Cl caused depolarization of mitochondria (loss of $\Delta \Psi_{\mathrm{m}}$ ) and evoked the release of cytochrome $\mathrm{c}$ into the cytoplasm in a dose and time-dependent manner, a characteristic for numerous stimuli that cause apoptosis via the mitochondrial pathway [15, 23].

Since the activity of the Bcl-2 family proteins can be affected in cancer cells or modulated upon exposure to chemotherapeutic drugs, we have investigated the contribution of the major players in this family to 5'-Cl-induced apoptosis. According to their chemical structure, factors in this family are classified into two groups; the $\mathrm{BH} 3$ and $\mathrm{BH} 4$ proteins. Proapoptotic proteins of the BH3 group, Bax and Bak, inhibit the antiapoptotic activity of $\mathrm{BH} 4$ group proteins, $\mathrm{Bcl}-2$ and $\mathrm{Bcl}-\mathrm{X}_{\mathrm{L}}$, by forming heterodimers and exhibit proapoptotic activity by forming homodimers $[24,25]$. An increase in the ratio of Bax/Bcl-2 or Bak/ Bcl$\mathrm{x}_{\mathrm{L}}$ stimulates Bax and Bak to form channels in the outer mitochondria membrane allowing cytochrome $\mathrm{c}$ to escape into the cytosol to stimulate the Apaf-1-caspase-9 apoptosome, leading to activation of caspase-3 [23]. We found that treatment of HL-60 cells with 5'-Cl resulted in a substantial decrease in the expression of Bcl-2 protein and mRNA, while the levels of Bax, Bak and Bcl-xL were not affected. In addition, the compound also induced hyperphosphorylation of Bcl-2 and, subsequently, loss of its functional association with Bax as demonstrated by co-immunoprecipitation assays. These results may be responsible 


\section{Cellular Physiology Cell Physiol Biochem 2015;35:1958-1974

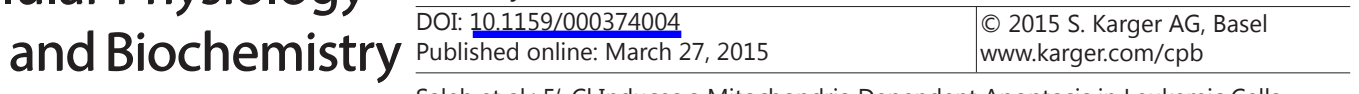

for the activation of apoptosis through $5^{\prime}-\mathrm{Cl}$, which included disruption of mitochondrial membrane potential and increased leakage of cytochrome $c$.

Treatment of HL-60 cells with 5'-Cl resulted in a dose-dependent increase in the activity of initiator caspases (-2, -8 and -9) and executioner caspases (-3/-7 and -6). However, our findings that z-VAD-FMK only partially rescued 5 -Cl-treated cells from apoptosis and depolarization of mitochondria suggest the possible involvement of caspase-independent pathways of cell death. Interestingly, the presence of z-VAD-FMK also did not inhibit ATP depletion (data not shown), suggesting that the 5'-Cl-induced dysfunctioning of the mitochondria is independent from caspase activation.

Our results show that $5^{\prime}-\mathrm{Cl}$ is able to inactivate Bcl-2 in HL-60 cells via mechanisms that include transcription control and hyperphosphorylation. Several mechanisms have been shown to inactivate Bcl-2. Activated caspases can cleave and inactivate Bcl-2 [26]. The control of $\mathrm{Bcl}-2$ protein levels may also occur through ubiquitination-dependent degradation by proteasomes, which is governed by its phosphorylation status [27]. Although the 5'-Cl-dependent caspase-cleavage or proteasomal degradation of Bcl-2 cannot be ruled out, we could not detect the presence of short form (23-kD) of protein in our Western blots or ubiquitinated form in Bcl-2 immunoprecipitates from HL-60 treated cells (data not shown). On the other hand, the levels of $B c l-2$ mRNA were substantially decreased in a dosedependent manner, suggesting that 5 '-Cl interferes with $B c l-2$ gene expression. Since HL-60 cells are deficient in functional p53 [28, 29], this tumor suppressor does not seem to be involved in regulating $B c l 2$ [30].

Under normal physiological conditions, Bcl-2 is phosphorylated on $\mathrm{Ser}^{70}$ during M phase of cycle [31]. Phosphorylation of $\mathrm{Ser}^{70}$ is important for the antiapoptotic function of the protein [32]. In contrast, hyperphosphorylation on $\mathrm{Thr}^{69}$ and $\mathrm{Ser}^{87}$ was shown to inactivate Bcl-2 and abrogate its antiapoptotic role by impairing its association with Bax [33]. Our results show that 5 '-Cl induces a dose-dependent increase in Bcl-2 hyperphosphorylation that correlates with loss of its heterodimerization with Bax in HL-60 treated cells. These results are consistent with several previous reports showing hyperphosphorlylation of Bcl-2 was induced by several chemotherapeutic agents [27, 28, 34]. The key enzymes responsible for inactivation of Bcl-2 by hyperphosphorylation include protein kinase A [29], apoptosis signal regulating kinase-1 [35] and c-Jun N-terminal kinases (JNK) [33], which vary depending on the cell type and the stimulus [29]. Therefore, we are currently investigating the candidate kinase responsible for Bcl-2 phosphorylation in 5'-Cl treated HL-60 cells.

Chemotherapeutic drugs are able to kill cancer cells by increasing the formation of ROS, which will disrupt mitochondria leading to apoptosis [36]. Our data showed that $5^{\prime}-\mathrm{Cl}$ induced a dose and time-dependent increase in the levels of ROS in HL-60 cells. The findings that ROS scavengers NAC and PDTC substantially reduced depolarization of mitochondria and apoptosis support the critical role of ROS in the 5'-Cl-induced dysfunctioning of mitochondria and apoptosis. Interestingly, the combination of either ROS scavenger with z-VAD-FMK caused only a marginal reduction of mitochondrial depolarization, but significant inhibition of apoptosis over the ROS scavenger alone, suggesting that additional mechanisms might be involved in 5'-Cl-induced cytotoxicity. ROS has been reported to regulate the levels Bcl-2 through dephosphorylation-dependent proteasomal degradation [27, 37]. It remains, therefore, interesting to determine the effect of ROS scavengers NAC and PDTC on 5'-Clinduced phosphorylation of Bcl-2.

Certainly, the detailed elucidation of the pathways and the respective targets of 5 '-Cl involved in apoptosis are critical for its application in cancer therapy. Our results support that 5 '-Cl triggers the mitochondrial pathway of apoptosis. However, we cannot rule out the potential involvement of extrinsic receptor pathway(s) of apoptosis in 5'-Cl-treated cells. The later possibility is supported by the finding that 5 - $\mathrm{Cl}$ induced activation of caspase-8. However, whether activation of caspase-8 is mainly involved in $5^{\prime}$-Cl-induced apoptosis or consequent to activation of effector caspase- 3 triggered by the release of cytochrome $c$ to the cytosol remains to be investigated. Similarly, it is yet unclear whether 5 '-Cl-induced activation of caspase-2 is due to sequential activation of other caspases or response to potential direct 


\section{Cellular Physiology Cell Physiol Biochem 2015;35:1958-1974 \begin{tabular}{l|l} 
DOI: 10.1159/000374004 & O 2015 S. Karger AG, Basel
\end{tabular} and Biochemistry Published online: March 27, 2015 www.karger.com/cpb \\ Saleh et al.: $5^{\prime}-\mathrm{Cl}$ Induces a Mitochondria Dependent Apoptosis in Leukemic Cells}

action of the compound on damaging the DNA of HL-60 cells [38]. Furthermore, our finding that the combination of the z-VAD-FMK and ROS scavenges failed to fully inhibit apoptosis in treated cells, suggests that other mechanisms maybe involved in 5'-Cl-induced cell death. We have recently shown that 5 '-Cl inhibits the activities of CDK2 and CDK4, leading to cell cycle arrest at G0/G1 in HL-60 cells [19]. Considerable evidence suggests transition of cell cycle from G1 to S phase is controlled by MAPKs [39]. The potential involvements of MAPK signaling pathways in 5'-Cl-induced apoptosis are currently under our investigation.

In conclusion, we have demonstrated that 5 '-Cl inhibits the growth of HL-60 by inducing a caspase-dependent and independent apoptosis. The mechanisms of apoptosis are related to down-regulation and hyperphosphorylation of Bcl-2, along with the generation of ROS and disruption of mitochondrial $\Delta \Psi_{\mathrm{m}}$, followed by release of cytochrome c to the cytosol, which eventually leads to activation of caspases and apoptosis. These findings, in addition to the effect of this compound on inhibition of cell cycle progression, suggest its potential application in cancer therapy.

\section{Acknowledgments}

This project is supported by a research grant from King Abdulaziz City for Science and Technology (KACST; Grant number- AT-34-136, Riyadh, Kingdom of Saudi Arabia) for Saleh AM. El-Abadelah MM, Sabri SS and Zahra JA are supported by the Scientific Research Support Fund (SRSF; project number- mph/1/6/2011, Amman, Jordan). Publication cost is supported by King Abdullah International Medical Research Center (KAIMRC) in Riyadh, Saudi Arabia.

\section{Abbreviations}

5'-Cl ([(E)-1-(5'-Chloro-2'-oxoindolin-3'-ylidene)-6-ethyl-2,3,6,9-tetrahydro-2,9-dioxo-1H-pyrrolo[3,2-f]quinoline-8-carboxylic acid]); $\Delta \Psi_{\mathrm{m}}$ (Difference in mitochondrial transmembrane potential); ROS (Reactive oxygen species); Bcl-2 (B-cell lymphoma 2); Bcl-xL (B-cell lymphoma-extra-large); Bax (Bcl-2-associated X protein); Bak (Bcl-2 homologous antagonist killer); PARP (Poly (ADP-ribose) polymerase); PDTC, (Pyrrolidine dithiocarbamate); NAC (N-Acetyl Cysteine); z-VAD-FMK (N-Benzyloxycarbonyl-Val-Ala-Asp-fluoromethyl ketone); Ac-LEHD-pNA (N-acetyl-Leu-Glu-His-Asp-p-nitroanilide); Ac-IETD-pNA (N-acetyl-Ile-Glu-Thr-Asp-p-nitroanilide); Ac-DEVD-pNA (N-acetyl-Asp-Glu-Val-Asp-p-nitroanilide); Ac-VDVAD (N-acetyl-Val-Asp-Val-Ala-Asp-p-nitroanilide); Ac-VEID-pNA (N-acetyl-Val-Glu-Ile-Asp-p-nitroanilide); pNA (p-nitroanilide).

\section{Disclosure Statement}

The authors declare no conflict of interest.

\section{References}

1 Lowenberg B, Downing JR, Burnett A: Acute myeloid leukemia. N Engl J Med 1999;341:1051-1062.

-2 Stone RM, O'Donnell MR, Sekeres MA: Acute myeloid leukemia. Hematology Am Soc Hematol Educ Program 2004:98-117.

-3 Stirewalt DL, Meshinchi S, Radich JP: Molecular targets in acute myelogenous leukemia. Blood Rev 2003;17:15-23.

4 Xiao Z, Hao Y, Liu B, Qian L: Indirubin and meisoindigo in the treatment of chronic myelogenous leukemia in China. Leuk Lymphoma 2002;43:1763-1768. 


\section{Cellular Physiology Cell Physiol Biochem 2015;35:1958-1974 \begin{tabular}{l|l|l|l|l|l}
\hline DOI: 10.1159/000374004 & 2015 S. Karger AG, Basel
\end{tabular} and Biochemistry Published online: March 27, 2015 www.karger.com/cpb \\ Saleh et al.: 5'-Cl Induces a Mitochondria Dependent Apoptosis in Leukemic Cells}

-5 Sassatelli M, Bouchikhi F, Messaoudi S, Anizon F, Debiton E, Barthomeuf C, Prudhomme M, Moreau P: Synthesis and antiproliferative activities of diversely substituted glycosyl-isoindigo derivatives. Eur J Med Chem 2006;41:88-100.

6 Du DJ, Ceng QT: Effect of indirubin on the incorporation of isotope labeled precursors into nucleic acid and protein of tumor tissues. Chinese Trad Herb Drugs 1981;12:406-409.

7 Ji XJ, Zhang FR, Liu Y, Gu QM: Studies on the antineoplastic action of N-methylisoindigotin. Yao Xue Xue Bao 1985;20:247-251.

-8 Leclerc S, Garnier M, Hoessel R, Marko D, Bibb JA, Snyder GL, Greengard P, Biernat J, Wu YZ, Mandelkow EM, Eisenbrand G, Meijer L: Indirubins inhibit glycogen synthase kinase-3 beta and CDK5/p25, two protein kinases involved in abnormal tau phosphorylation in Alzheimer's disease. A property common to most cyclin-dependent kinase inhibitors? J Biol Chem 2001;276:251-260.

-9 Liu XM, Wang LG, Li HY, Ji XJ: Induction of differentiation and down-regulation of c-myb gene expression in ML-1 human myeloblastic leukemia cells by the clinically effective anti-leukemia agent meisoindigo. Biochem Pharmacol 1996;51:1545-1551.

10 Marko D, Schatzle S, Friedel A, Genzlinger A, Zankl H, Meijer L, Eisenbrand G: Inhibition of cyclindependent kinase 1 (CDK1) by indirubin derivatives in human tumour cells. Br J Cancer 2001;84:283-289.

11 Mingxin Z, Yan L, Hongbo W, Jianhua Z, Hongyan L, He L, Hongqi X, Sen Z, Xiaoguang C: The antitumor activity of meisoindigo against human colorectal cancer HT-29 cells in vitro and in vivo. J Chemother 2008;20:728-733.

12 Moon MJ, Lee SK, Lee JW, Song WK, Kim SW, Kim JI, Cho C, Choi SJ, Kim YC: Synthesis and structure-activity relationships of novel indirubin derivatives as potent anti-proliferative agents with CDK2 inhibitory activities. Bioorg Med Chem 2006;14:237-246.

13 Zhao P, Li Y, Gao G, Wang S, Yan Y, Zhan X, Liu Z, Mao Z, Chen S, Wang L: Design, synthesis and biological evaluation of $\mathrm{N}$-alkyl or aryl substituted isoindigo derivatives as potential dual cyclin-dependent kinase 2 (CDK2)/glycogen synthase kinase 3beta (GSK-3beta) phosphorylation inhibitors. Eur J Med Chem 2014;86:165-174.

-14 Xu JJ, Dai XM, Liu HL, Guo WJ, Gao J, Wang CH, Li WB, Yao QZ: A novel 7-azaisoindigo derivative-induced cancer cell apoptosis and mitochondrial dysfunction mediated by oxidative stress. J Appl Toxicol 2011;31:164-172.

15 Kaufmann SH, Earnshaw WC: Induction of apoptosis by cancer chemotherapy. Exp Cell Res 2000;256:4249.

16 Adams JM, Cory S: Apoptosomes: engines for caspase activation. Curr Opin Cell Biol 2002;14:715-720.

17 Saleh A, Srinivasula SM, Acharya S, Fishel R, Alnemri ES: Cytochrome c and dATP-mediated oligomerization of Apaf-1 is a prerequisite for procaspase-9 activation. J Biol Chem 1999;274:17941-17945.

-18 Saleh AM, Al-As'ad RM, El-Abadelah MM, Sabri SS, Zahra JA, Alaskar AS, Aljada A: Synthesis and biological evaluation of new pyridone-annelated isoindigos as anti-proliferative agents. Molecules 2014;19:1307613092.

19 Saleh AM, Aljada A, El-Abadelah MM, Taha MO, Sabri SS, Zahra JA, Aziz MA: The Anticancer Activity of the Substituted Pyridone-Annelated Isoindigo (5'-Cl) Involves G0/G1 Cell Cycle Arrest and Inactivation of CDKs in the Promyelocytic Leukemia Cell Line HL-60. Cell Physiol Biochem 2015;35:1943-1957.

20 Saleh AM, Aljada A, Rizvi SA, Nasr A, Alaskar AS, Williams JD: In vitro cytotoxicity of Artemisia vulgaris L. essential oil is mediated by a mitochondria-dependent apoptosis in HL-60 leukemic cell line. BMC Complement Altern Med 2014;14:226.

21 Chen JH, Cao JL, Chu YL, Wang ZL, Yang ZT, Wang HL: T-2 toxin-induced apoptosis involving Fas, p53, Bcl-xL, Bcl-2, Bax and caspase-3 signaling pathways in human chondrocytes. J Zhejiang Univ Sci B 2008;9:455-463.

22 de Bruin EC, Medema JP: Apoptosis and non-apoptotic deaths in cancer development and treatment response. Cancer Treat Rev 2008;34:737-749.

23 Hu W, Kavanagh JJ: Anticancer therapy targeting the apoptotic pathway. Lancet Oncol 2003;4:721-729.

24 Hirotani M, Zhang Y, Fujita N, Naito M, Tsuruo T: NH2-terminal BH4 domain of Bcl-2 is functional for heterodimerization with Bax and inhibition of apoptosis. J Biol Chem 1999;274:20415-20420.

25 Lutz RJ: Role of the BH3 (Bcl-2 homology 3) domain in the regulation of apoptosis and Bcl-2-related proteins. Biochem Soc Trans 2000;28:51-56. 


\section{Cellular Physiology Cell Physiol Biochem 2015;35:1958-1974 \begin{tabular}{l|l} 
DOI: 10.1159/000374004 & O 2015 S. Karger AG, Basel \\
and Biochemistry Published online: March 27, 2015 & www kat
\end{tabular} Saleh et al.: $5^{\prime}-\mathrm{Cl}$ Induces a Mitochondria Dependent Apoptosis in Leukemic Cells}

26 Fadeel B, Hassan Z, Hellstrom-Lindberg E, Henter JI, Orrenius S, Zhivotovsky B: Cleavage of Bcl-2 is an early event in chemotherapy-induced apoptosis of human myeloid leukemia cells. Leukemia 1999;13:719-728.

27 Azad N, Iyer AK, Manosroi A, Wang L, Rojanasakul Y: Superoxide-mediated proteasomal degradation of Bcl-2 determines cell susceptibility to $\mathrm{Cr}(\mathrm{VI})$-induced apoptosis. Carcinogenesis 2008;29:1538-1545.

28 Wang L, Chanvorachote P, Toledo D, Stehlik C, Mercer RR, Castranova V, Rojanasakul Y: Peroxide is a key mediator of Bcl-2 down-regulation and apoptosis induction by cisplatin in human lung cancer cells. Mol Pharmacol 2008;73:119-127.

-29 Blagosklonny MV, Giannakakou P, el-Deiry WS, Kingston DG, Higgs PI, Neckers L, Fojo T: Raf-1/bcl-2 phosphorylation: a step from microtubule damage to cell death. Cancer Res 1997;57:130-135.

-30 Livingstone LR, White A, Sprouse J, Livanos E, Jacks T, Tlsty TD: Altered cell cycle arrest and gene amplification potential accompany loss of wild-type p53. Cell 1992;70:923-935.

- 31 Deng X, Kornblau SM, Ruvolo PP, May WS, Jr.: Regulation of Bcl2 phosphorylation and potential significance for leukemic cell chemoresistance. J Natl Cancer Inst Monogr 2001:30-37.

-32 Ito T: [Overexpression of bcl-2 suppresses apoptosis in the human leukemia cell line TF-1]. Rinsho Byori 1997;45:628-637.

-33 Scatena CD, Stewart ZA, Mays D, Tang LJ, Keefer CJ, Leach SD, Pietenpol JA: Mitotic phosphorylation of Bcl-2 during normal cell cycle progression and Taxol-induced growth arrest. J Biol Chem 1998;273:3077730784.

-34 Luanpitpong S, Chanvorachote P, Nimmannit U, Leonard SS, Stehlik C, Wang L, Rojanasakul Y: Mitochondrial superoxide mediates doxorubicin-induced keratinocyte apoptosis through oxidative modification of ERK and Bcl-2 ubiquitination. Biochem Pharmacol 2012;83:1643-1654.

- 35 Yang WH, Fong YC, Lee CY, Jin TR, Tzen JT, Li TM, Tang CH: Epigallocatechin-3-gallate induces cell apoptosis of human chondrosarcoma cells through apoptosis signal-regulating kinase 1 pathway. J Cell Biochem 2011;112:1601-1611.

-36 Cai J, Jones DP: Superoxide in apoptosis. Mitochondrial generation triggered by cytochrome c loss. J Biol Chem 1998;273:11401-11404.

-37 Dimmeler S, Breitschopf K, Haendeler J, Zeiher AM: Dephosphorylation targets Bcl-2 for ubiquitindependent degradation: a link between the apoptosome and the proteasome pathway. J Exp Med 1999;189:1815-1822.

-38 Kumar S: Caspase 2 in apoptosis, the DNA damage response and tumour suppression: enigma no more? Nat Rev Cancer 2009;9:897-903.

39 Wilkinson MG, Millar JB: Control of the eukaryotic cell cycle by MAP kinase signaling pathways. Faseb J 2000;14:2147-2157. 